\title{
Unusual endometriosis mimicking disseminated cancer after hysterectomy in a young woman
}

\author{
Catarina Reis-de-Carvalho (1) , ${ }^{1,2}$ Catarina Castro, ${ }^{2}$ Filipa Osório ${ }^{2,3}$
}

${ }^{1}$ PTCSRT, Harvard University, Cambridge, Massachusetts, USA ${ }^{2}$ Obstetrics, Gynecology and Reproductive Medicine, Centro Hospitalar Universitário Lisboa Norte EPE, Lisbon, Portugal ${ }^{3}$ Obstetrics-Gynaecology, Hospital da Luz, Lisbon, Portugal

\section{Correspondence to}

Catarina Reis-de-Carvalho; catarinareiscarvalho@gmail.com

Accepted 23 December 2020

Check for updates

(c) BMJ Publishing Group Limited 2021. No commercial re-use. See rights and permissions. Published by BMJ.

To cite: Reis-de-Carvalho C, Castro C, Osório F. BMJ Case Rep 2021;14:e241002. doi:10.1136/bcr-2020241002

\section{DESCRIPTION}

A 31-year-old woman with a recent onset of abdominal pain with lumbar irradiation and nausea was admitted to our center because of the finding of a suspicious intra-abdominal mass. The patient had a previous diagnosis of deep infiltrating endometriosis since 2009. She was followed in another hospital where she underwent two surgeries: a laparoscopic ovarian cystectomy and a myomectomy in 2009 and an open hysterectomy and bilateral ovarian cystectomy in 2015 .

MRI (figure 1) revealed a broad, solid abdominal mass measuring $17 \times 13 \times 16 \mathrm{~cm}$, with vegetations and haemorrhagic cystic areas and with no apparent relation with adnexal areas, firmly adherent to the rectosigmoid transition. She also had elevated serum cancer antigen (CA) 125 level $(641 \mu / \mathrm{mL})$, normal HE4 human epididymis protein 4 (HE4 $151 \mathrm{pM}$ ) and ROMA (ovarian malignancy risk algorithm).

Diagnostic laparoscopy revealed a frozen pelvis, with multiple adhesions of the bowel that covered an abdominal-pelvic mass of about $15 \mathrm{~cm}$, without an identified starting point. The upper abdomen had no changes. The surgeons' clinical impression was that it was a neoformative process. Extemporaneous histopathological examination during surgery was inconclusive. Due to the strong suspicion of malignancy, the surgical team decided to convert to laparotomy.

During the procedure was performed adhesiolysis, excision of the retroperitoneal mass (figure 2) and bilateral salpingectomy. Omentectomy was performed because suspicious nodular lesions were identified in the epiploon. Lymphadenectomy of two clinically palpable lymph nodes in the left iliac artery bifurcation was also performed.

Contrary to what the macroscopic examination predicted, the postoperative pathology examination revealed that the mass was covered with a monolayer of normal-looking endometrial glands and stroma consistent with common endometriosis. The patient's recovery was uneventful. Three months after the operation, the patient was asymptomatic.

The aetiology of endometriosis is unclear. In this particular case, we can speculate that the mechanism involved in the formation of this mass was a coelomic metaplasia associated with an abnormal immune response that leads to cell growth, inflammation and fibrosis. ${ }^{1}$ Endometriosis can be easily confounded with neoplasia and has itself a malignant transformation potential as high as $0.5 \%-1.0 \% .^{2}$ The most common malignant tumours in this setting are endometrioid adenocarcinoma and clear cell adenocarcinoma. ${ }^{34}$

This case is relevant because of the unusual presentation and the gross morphology of endometriosis, similar to a malignant tumour. In this case, the

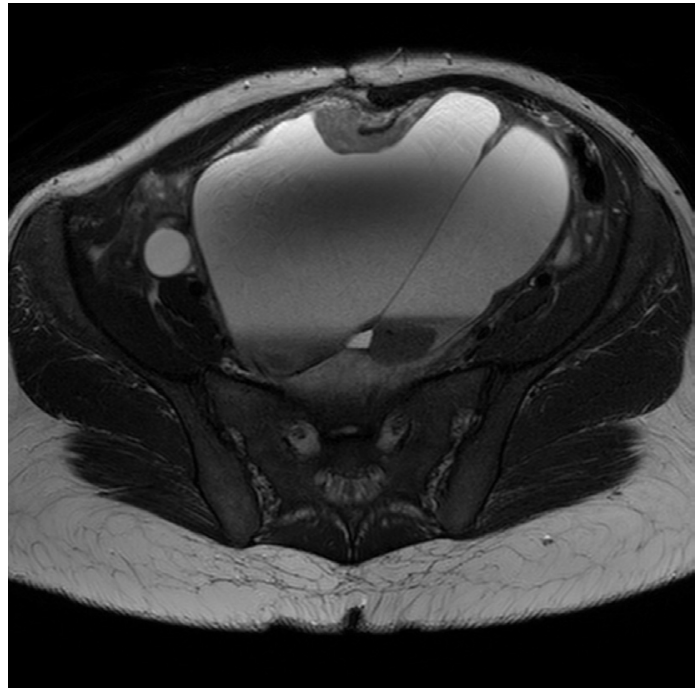

Figure 1 Axial section of a T2-weighted pelvic MRI showing a multiseptate pelvic mass measuring $17 \times 13 \times 16$ $\mathrm{cm}$ with haemorrhagic content in different stages of haemoglobin degradation, without fat content and with partly pseudoseptated and serpiginous appearance wrapped around itself, which seems to correspond to a probable haematosalpinx associated with areas of parietal thickening, without restriction to diffusion.

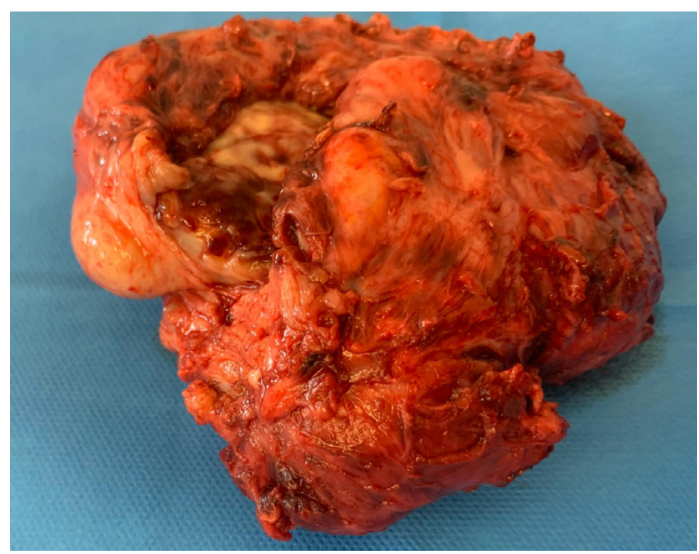

Figure 2 Surgical specimen that represents the retroperitoneal mass with $18 \times 11 \times 9 \mathrm{~cm}$ was adherent to the retrosigmoidal transition and was of hard consistency, irregular contours and whitish appearance. It is not possible to individualise any structures. Note that the mass does not have the typical grossly appearance of endometriosis, such as gelatinous lesions of reddish colour (light or dark), light colour (yellow or brown) or dark colour (black or blue). 
preoperative investigation supported the hypothesis of recurrence of endometriosis. However, the macroscopic appearance of the solid pelvic lesion was in favour of a neoformative process. It is unusual that the macroscopic appearance is contrary to the microscopic diagnosis, so this case reminds us of the difficulties in managing these cases even in experienced centres. Although it was not conclusive in our case, the intraoperative pathological examination (frozen-section analysis) increases the sensitivity and specificity for the patient risk classification and, thus, is a useful tool for surgical decision. ${ }^{5}$

\section{Learning points}

- Endometriosis' recurrence is possible after hysterectomy, especially in case of preservation of ovaries. Thus, isolated hysterectomy is a poor treatment for endometriosis, particularly in young women.

- Gynaecologists and oncologists should be aware that endometriosis may mimic ovarian malignancy.

- Multipoint biopsies and frozen-section analysis during surgery are important to increase the accuracy of diagnosis and treatment.

Contributors CR-de-C: Conception of the work, design of the work, acquisition of data, analysis of data and Interpretation of data. CC: Acquisition of data and analysis of data. FO: Revising the work critically for important intellectual content, final approval of the version to be published and agree to be accountable for all aspects of the work in ensuring that questions related to the accuracy or integrity of any part of the work are appropriately investigated and resolved.

Funding The authors have not declared a specific grant for this research from any funding agency in the public, commercial or not-for-profit sectors.

Competing interests None declared.

Patient consent for publication Obtained.

Provenance and peer review Not commissioned; externally peer reviewed.

\section{ORCID iD}

Catarina Reis-de-Carvalho http://orcid.org/0000-0002-5962-1560

\section{REFERENCES}

1 Zwierzchowska A, Panek G, Gajewska M, et al. Endometriotic lesions mimicking advanced ovarian cancer -A case report and a review of the literature. Eur J Gynaecol Oncol 2017;38:303-7

2 Matias-Guiu X, Stewart CJR. Endometriosis-Associated ovarian neoplasia. Pathology 2018;50:190-204.

3 Kajiyama H, Suzuki S, Yoshihara M, et al. Endometriosis and cancer. Free Radic Biol Med 2019;133:186-92.

4 Zondervan KT, Becker CM, Koga K, et al. Endometriosis. Nat Rev Dis Primers 2018;4:9.

5 Santoro A, Piermattei A, Inzani F, et al. Frozen section accurately allows pathological characterization of endometrial cancer in patients with a preoperative ambiguous or Inconclusive diagnoses: our experience. BMC Cancer 2019;19:6.

Copyright 2021 BMJ Publishing Group. All rights reserved. For permission to reuse any of this content visit

https://www.bmj.com/company/products-services/rights-and-licensing/permissions/

BMJ Case Report Fellows may re-use this article for personal use and teaching without any further permission.

Become a Fellow of BMJ Case Reports today and you can:

- Submit as many cases as you like

- Enjoy fast sympathetic peer review and rapid publication of accepted articles

- Access all the published articles

Re-use any of the published material for personal use and teaching without further permission

\section{Customer Service}

If you have any further queries about your subscription, please contact our customer services team on +44 (0) 2071111105 or via email at support@bmj.com.

Visit casereports.bmj.com for more articles like this and to become a Fellow 